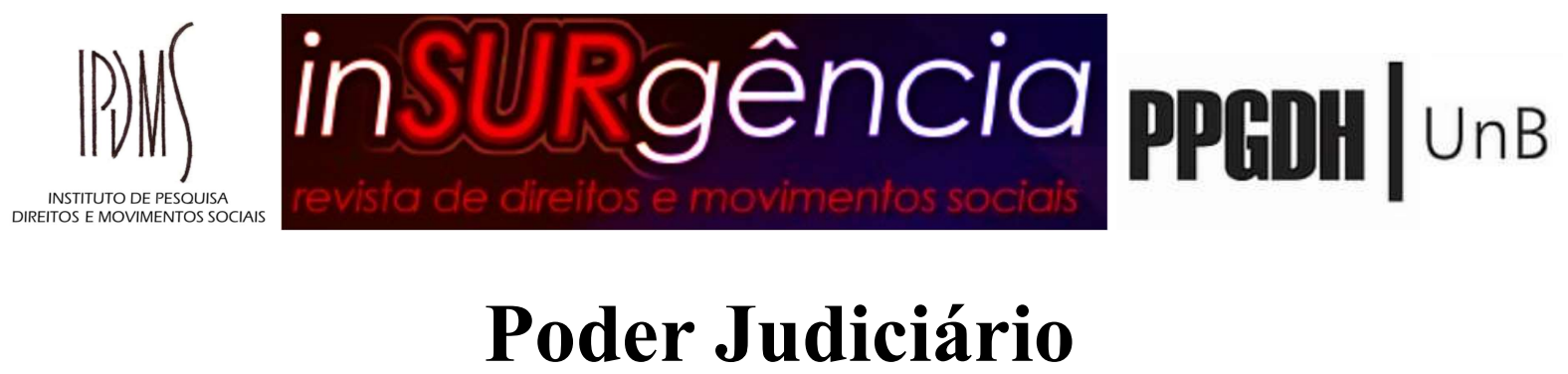

\title{
JUSTIÇA FEDERAL
}

\author{
Seção Judiciária do Rio Grande do Sul \\ $9^{\text {a }}$ Vara Federal de Porto Alegre
}

Rua Otávio Francisco Caruso da Rocha, 600, $7^{\circ}$ andar - Ala Oeste - Bairro: Praia de Belas - CEP: 90010395 - Fone: (51) 32149255 - Email: rspoa09sec@jfrs.jus.br

\author{
AÇÃO CIVIL PÚBLICA No 5069057-47.2019.4.04.7100/RS \\ AUTOR: ASSOCIACAO INDIGENA POTY GUARANI \\ ADVOGADO: CARLOS RÖCKER (OAB SC023047) \\ AUTOR: ASSOCIACAO ARAYARA DE EDUCACAO E CULTURA \\ ADVOGADO: CARLOS RÖCKER (OAB SC023047) \\ RÉU: FUNDAÇÃO ESTADUAL DE PROTEÇÃO AMBIENTAL HENRIQUE LUIS ROESSLER - FEPAM \\ RÉU: COPELMI MINERAÇÃO LTDA. \\ RÉU: FUNDAÇÃO NACIONAL DO ÍNDIO - FUNAI \\ MPF: MINISTÉRIO PÚBLICO FEDERAL
}

\section{DESPACHO/DECISÃO}

\section{RELATÓRIO}

Trata-se de ação civil pública proposta pela Associação Arayara de Educação e Cultura e a Associação Indígena Poty Guarani em face da Fundação Nacional do Índio FUNAI, da Copelmi Mineração Ltda. e da Fundação Estadual de Proteção Ambiental Henrique Luís Roessler - Fepam, objetivando, em apertada síntese, a anulação do processo de licenciamento ambiental do empreendimento denominado 'Mina Guaíba', em razão da ausência no Estudo de Impacto Ambiental apresentado pelo empreendedor de componente indígena referente à comunidade Mbyá-Guarani Guajayvi, bem como da consulta prévia à referida comunidade prevista na Convenção 169 da OIT.

A parte autora requereu: "Seja concedida a tutela cautelar antecedente pleiteada, para, in limine litis e inaudita altera pars, SUSPENDER IMEDIATAMENTE E NO ESTADO EM QUE SE ENCONTRA O PROCESSO DE LICENCIAMENTO que tramita junto

a FEPAM a requerimento da COPELMI, e que pretende obter o licenciamento para instalação do denominado PROJETO MINA GUAÍBA, fixando multa diária em caso de descumprimento;" (ev. 1). Alegou exclusão da comunidade indígena, notadamente a Aldeia TeKoá Guajayvi, localizada no entorno do empreendimento, dos estudos de impactos ambientais. Juntou documentos (ev. 1). 


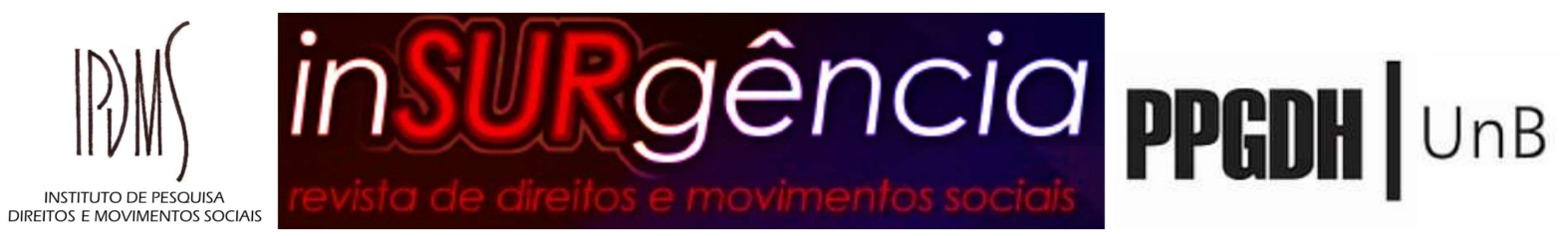

Por este Juízo foi determinada a intimação da parte autora a regularizar as procurações, sendo determinada vista ao MPF após a regularização (ev. 3).

Os autores juntaram novas procurações (ev. 7).

Intimado, o Ministério Público Federal apresentou parecer (ev. 11), manifestando-se favoravelmente ao pedido de tutela cautelar dos autores para suspensão imediata do processo de licenciamento do projeto Mina Guaíba, por haver "prova inequívoca da verossimilhança do direito, isto é, da necessidade de inclusão de Componente Indígena no EIARIMA e de realização de consulta prévia livre e informada às comunidades indígenas afetadas", acrescentando "também é evidente o risco ao direito da comunidade Mbyá- Guarani Guaijayvi pela continuidade do processo de licenciamento.". Juntou documentos (ev. 11).

Foram intimadas a FEPAM, a FUNAI e a Copelmi Mineração Ltda. a se manifestarem sobre o pedido de antecipação de tutela, conforme determinação constante do ev. 13.

A empresa ré Copelmi Mineração Ltda. pronunciou-se (ev. 19). Disse que as procurações juntadas no ev. 7 seguem irregulares porque: 1) faltaria comprovação de que Juliano Bueno de Araújo, apontado como representante da Associação Arayara, continue sendo seu atual Diretor Presidente; e 2) porque o instrumento da procuração juntada pela Associação Arayara não é público, conforme exigência do parágrafo único do art. 24 de seu Estatuto. Disse, ainda, que, com relação à Associação indígena, o respectivo estatuto social foi juntado de forma incompleta aos autos. Aduziu que o direito alegado pelos autores já está sendo respeitado, eis que Estudo de Componente Indígena - ECI será realizado pela Copelmi tão logo a Funai expeça o Termo de Referência Específico - TRE. Disse que a participação da FUNAI no licenciamento ambiental garante a realização da consulta prevista pela Convenção 169 da OIT. Salientou que o Estudo de Componente Indígena será realizado pela Copelmi, que nunca se opôs a tal realização. Disse que a empresa está aguardando a expedição do respectivo Termo de Referência Especificado - TRE pela FUNAI, atualmente em elaboração, que além de ser de competência deste ente, é essencial para a delimitação do conteúdo a ser estudado. Salientou que, em casos de empreendimentos minerários situados fora da Amazônia Legal, presumem-se impactos diretos se a terra indígena estiver localizada dentro do raio de $8 \mathrm{~km}$ do empreendimento. Entende pela existência de uma terra indígena em estudo no entorno do empreendimento: a Terra Indígena em estudo Arroio do Conde, no Município de Eldorado do Sul. Disse que feitas essas verificações, a partir dos dados públicos disponibilizados pela própria FUNAI, a Copelmi estava segura quanto à regularidade dos procedimentos licitatórios que vinham até então sendo adotados. Disse que, em julho de 2019, recebeu solicitação da FUNAI sobre dados locacionais do projeto 'Mina Guaíba'. Disse que as informações foram prestadas pela Copelmi em 07/08/2019 e que, até dezembro de 2019, ainda aguardava a resposta da FUNAI, quanto à necessidade de sua participação no licenciamento ambiental como de ser necessária a realização de Estudo do Componente Indígena - ECI. Disse que, em 14/01/2019, requereu à FUNAI a expedição do Termo de Referência Específico para poder dar início ao ECI. Disse que a realização do ECI, que motivou o ingresso da presente ação, está devidamente resguardada, sendo que não foi iniciada porque aguarda o Termo de Referência Específico a ser expedido pela FUNAI, que 


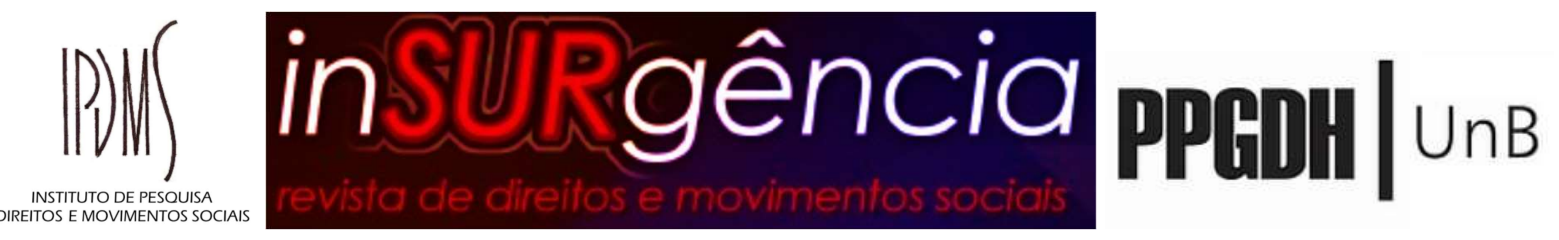

norteará o estudo específico. Disse que da mesma forma encontra-se resguardada a consulta prévia de que trata a Convenção 169 da OIT, porquanto já há participação da FUNAI no processo de licenciamento ambiental do Projeto 'Mina Guaíba'. Salientou que o processo de licenciamento encontra-se na fase de Licença Prévia - LP, etapa destinada a declarar a viabilidade ambiental, ou não, do empreendimento proposto, não havendo a menor necessidade/utilidade da tutela judicial requerida. Registrou, por fim, que "embora a Aldeia (TeKoá) Guajayvi não conste como terra indígena na base de dados da FUNAI [independentemente da modalidade ou fase de regularização], ela teve a sua presença identificada pelo órgão indigenista no âmbito do processo administrativo $n^{o}$ 08620.007497/2019-10, onde este também consignou a informação de que 'A Funai está realizando tratativas com o Governo do Rio Grande do Sul para a possibilidade de repasse desta área para os indígenas' [OUT9, pg. 8]. Tal área, contudo, está localizada dentro do Horto Carola, de propriedade da Companhia Estadual de Energia Elétrica - CEEE, o qual está sendo objeto de investigação detalhada de contaminação do solo, tendo em vista o funcionamento pretérito de uma Unidade de Preservação de Madeira que operava no local. O procedimento de investigação é resultado de um Termo de Compromisso de Ajustamento de Conduta firmado entre o Ministério Público do Estado do Rio Grande do Sul e a CEEE, cujos estudos ainda se encontram em andamento, segundo informou a FEPAM [OUT9, pg. 1- 2]. Considerando que a contaminação desta área já havia motivado a retirada de famílias do Movimento Sem Terra - MST que haviam ocupado parte do Horto Carola, desocupação esta acordada no bojo de ação judicial sentenciada por V.Exa.8, a Copelmi informou a FUNAI a respeito, assim como endereçou questionamento por e-mail à FEPAM, responsável pelo licenciamento ambiental da descontaminação, acerca da possibilidade/segurança relacionada à permanência das famílias indígenas naquele local. Em resposta, a FEPAM informou não ter conhecimento do agrupamento indígena no imóvel, mas que havia provocado a CEEE para se manifestar a respeito [OUT8, pg. 34, OUT9, pg. 1-2]." (ev. 19). Requereu, ao final: "(i) o indeferimento da inicial, por irregularidade na representação dos Autores, nos termos dos arts. $76, \S 1^{\circ}, I, 320,321$ e art. 330, IV, todos do CPC, conforme detalhado no ponto I; (ii) o indeferimento da inicial, por falta de interesse processual dos Autores, nos termos do art. 330, III do CPC conforme detalhado nos pontos II e III; (iii) o indeferimento da tutela provisória, caso V.Exa. supere as preliminares acima, por ausência dos requisitos do art. 300 do CPC, nos termos detalhados nos pontos II e III." (ev. 19). Juntou documentos (ev. 19).

A FEPAM manifestou-se (ev. 22), alegando a regularidade do processo de licenciamento e da inexistência de risco de danos. Disse que, em 17/10/2018, a ré Copelmi requereu a instauração de processo administrativo para obtenção de Licença Prévia - LP para o projeto denominado 'Mina Guaíba', que tomou o número 6354-05.67/18-1, cujo objeto principal é a extração mineral de carvão em área de 5.000 hectares localizada entre os municípios gaúchos de Eldorado do Sul e de Charqueadas. Disse que a LP é concedida pelo órgão ambiental na fase preliminar de planejamento do empreendimento, nos termos do art. $8^{\circ}$, I, da Res. 237/97 do CONAMA. Disse que a LP aprova a localização e a concepção do empreendimento e estabelece os requisitos básicos e condicionantes a serem atendidos nas próximas fases de implementação da atividade. Disse ser no mesmo sentido o art. 56, I do Código Estadual do Meio Ambiente (Lei Estadual 11.520/2000). Aduziu que a LP, quando concedida pelo órgão ambiental, não autoriza a implantação do empreendimento, apenas aprova a sua localização e concepção. Disse que, para a implantação da atividade, é necessária a obtenção da Licença de Instalação - LI, em conformidade com o art. $8^{\circ}$, II, da Res. 237/97 do CONAMA e art. 56, II, da Lei Estadual $n^{\circ} 11.520 / 2000$. Destacou que o 


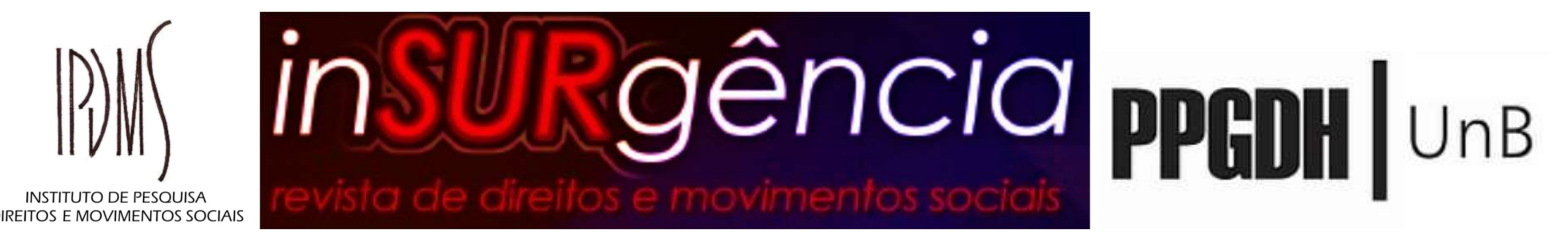

processo de licenciamento segue o rito previsto no art. 10 da Res. 237/97 do CONAMA. Disse que, para instalação de atividade potencialmente causadora de significativa degradação ambiental, o Poder Público deverá exigir o estudo prévio de impacto ambiental, nos termos do art. 225, $\S 1^{\circ}$, IV, da CF/88. Disse, ainda, que o art. $2^{\circ}$, IX, da Res. 1/86 do CONAMA determina a elaboração de estudo de impacto ambiental e do respectivo relatório de impacto ambiental (EIA/RIMA) para o licenciamento das atividades modificadoras do meio ambiente para atividades de extração de minério. Informou que o pedido de LP da ré Copelmi foi instruído com EIA/RIMA. Destacou, ainda, que a Fepam realizou análise prévia dos documentos e estudos ambientais apresentados pela ora ré Copelmi e que, a partir dessa análise, o órgão ambiental solicitou, em 17/12/2018, que a empresa apresentasse uma série de esclarecimentos e de complementações. Teceu considerações sobre a legislação referente às audiências públicas, indicando ser o espaço garantido à participação da sociedade, sendo autêntico instrumento da democracia participativa, transcrevendo julgado sobre a questão. Teceu considerações sobre ser a audiência pública procedimento prévio do licenciamento, que não supõe a existência de um EIA/RIMA perfeito, eis que contribui para a perfeição possível da análise do empreendimento e do instrumento licenciatório. Disse que, no caso dos autos, realizou duas audiências públicas (uma, no município de Charqueadas, em 14/03/2019 e a outra, no município de Eldorado do Sul, no dia 27/06/2019). Disse que ambas foram previamente divulgadas em conformidade com o art. 85, II da Lei Estadual 11.520/2000. Disse que, conforme reconhecido pelos autores na inicial, depois das duas audiências, a Fepam concedeu prazo para a apresentação de manifestações dos interessados. Disse que, a partir das manifestações, a Fepam notificou novamente a ré Copelmi, em 12/08/2019, solicitando novos esclarecimentos e complementações no prazo de 120 dias a findar em 10/12/2019. Disse que, em 10/12/2019, a ré Copelmi requereu a prorrogação de prazo por mais 120 dias, pleito permitido pelo art. 58, parágrafo único, da Lei Estadual 11.520/2000. Disse que observou todas as regras de licenciamento ambiental até o momento, garantindo diversas oportunidades para a manifestação livre e informada de todos os interessados. Destacou que não concluiu a análise do EIA/RIMA apresentado pela ora ré Copelmi. Disse que resta pendente a apresentação das complementações solicitadas pelo órgão ambiental. Explicitou que, dentre as solicitações feitas pela Fepam, foram exigidas complementações de informações relacionadas aos aspectos socioeconômicos, dentre elas, as relacionadas às possíveis terras indígenas nas adjacências ou proximidades do empreendimento, sustentando que somente depois da apresentação destas complementações é que o órgão ambiental poderá emitir os pareceres técnico e jurídico a respeito do EIA/RIMA apresentados pela ré Copelmi. Referiu que, sendo a resposta da empresa insuficiente, o órgão ambiental ainda poderá reiterar a solicitação, conforme rito previsto na Res. 237/97 do CONAMA. Defendeu que, conforme precedente do TRF4, a legislação não exige que o EIA seja exauriente, sendo possíveis complementações mesmo depois da concessão de licença ambiental. Disse que não há que se falar em nulidade do processo de licenciamento ambiental, muito menos em danos ambientais decorrentes da instalação do empreendimento. Disse que ainda não foi elaborado parecer técnico conclusivo sobre os estudos apresentados pelo empreendedor que antecede a concessão da licença prévia. Disse significar que ainda não foram aprovadas pelo órgão ambiental a localização e a concepção do empreendimento proposto pela ré Copelmi. Registrou que, mesmo que haja a concessão da LP, não haverá danos ambientais, uma vez que a implantação do empreendimento não é autorizada com a licença prévia, dependendo para tanto da obtenção da LI. Sustentou, por fim, de forma destacada, que não possui qualquer interesse em se opor à interveniência da FUNAI, referindo que, conforme ofício de informação da Divisão de Mineração da Fepam 


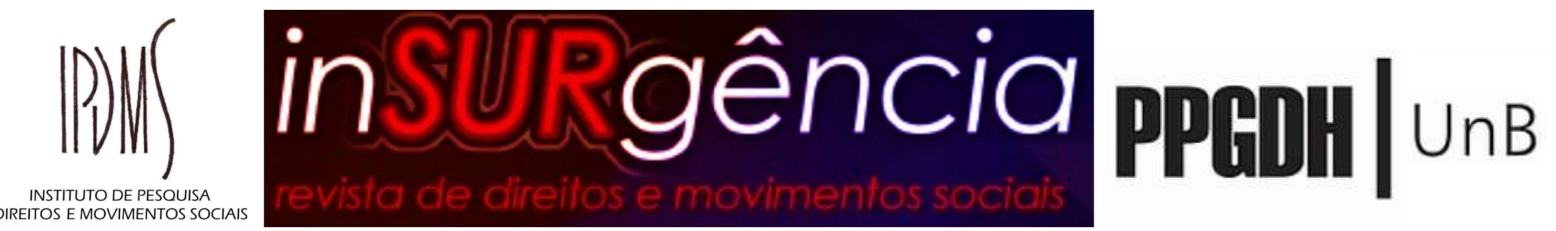

ao empreendedor, aguarda resposta quanto à elaboração dos estudos referentes ao componente indígena. Requereu o indeferimento da tutela cautelar pleiteada pelos autores. Juntou documentos (ev. 22).

A FUNAI manifestou-se (ev. 25), trazendo primeiramente a Informação Técnica $n^{\circ} 17 / 2020$, elaborada pela Coordenação-Geral de Licenciamento Ambiental, in verbis:

2. Primeiramente, comunicamos que a Coordenação-Geral de Licenciamento Ambiental (CGLic) tomou conhecimento do referido empreendimento somente por meio de oficio encaminhado pelo Conselho Estadual dos Povos Indigenas (CEPI) e por meio de ofício da Procuradoria da República no Rio Grande do Sul encaminhado à unidade descentralizada da Funai em Porto Alegre, não tendo sido, portanto, instada pela Fundação Estadual de Proteção Ambiental Henrique Luis Roessler (FEPAM) a se manifestar no processo de licenciamento ambiental antes da emissão do Termo de Referência para elaboração do Estudo de Impacto Ambiental (EIA) do empreendimento.

3. Posto isso, informamos que, conforme a Instrução Normativa $n^{\circ} 02 / 15$ (1919858), para a manifestação conclusiva desta Coordenação acerca da necessidade ou não de procedimentos específicos para o componente indígena, foi necessária a verificação cartográfica do empreendimento em relação às terras indígenas e a consulta acerca da existência de reivindicações fundiárias indígenas na região.

4. Após a conclusão das análises pela Diretoria de Proteção Territorial (DPT) da Funai, constatou-se que o projeto encontra-se a $6.95 \mathrm{~km}$ da Terra Indígena Arroio do Conde, a 1.82 $\mathrm{km}$ da Aldeia Guajayví e a $6.12 \mathrm{~km}$ da reivindicação de área denominada Pekuruty/Arroio Divisa; portanto, dentro da distância estabelecida no Anexo I da Portaria Interministerial $n^{\circ}$ 60/15 para empreendimentos dessa tipologia fora da Amazônia Legal.

5. Diante disso, comunicamos que já se encontra em elaboração o Termo de Referência Específico para a realização do Componente Indígena do Estudo de Impacto Ambiental (CIEIA) e, tão logo seja concluído, será encaminhado para a FEPAM, com cópia para o empreendedor.

6. Informamos ainda que, em janeiro de 2019, por meio de carta encaminhada à Diretoria de Promoção ao Desenvolvimento Sustentável (DPDS) da Funai, a Copelmi Mineração informou que tomou conhecimento das conclusões da Funai acerca da análise técnico-cartográfica e da consulta às reivindicações fundiárias indígenas e solicitou que esta Fundação encaminhasse o Termo de Referência Específico para elaboração do CI-EIA para que pudesse dar seguimento à elaboração do estudo necessário.

7. Por fim, ressalta-se que, com relação à consulta prévia à realização de qualquer empreendimento que possa afetar os povos indígenas, a Funai, em cumprimento à sua missão de proteger e promover os direitos dessas comunidades e ao disposto na Convenção $n^{\circ} 169$ da Organização Internacional do Trabalho, assegura, durante o processo de licenciamento, que os povos sejam consultados.

8. Quando as etnias já possuem Protocolos de Consulta, esta Fundação adequa o processo de licenciamento aos requisitos estabelecidos pelas comunidades. Quando determinado povo indígena não tem um Protocolo de Consulta, tal consulta é diluída em vários momentos do licenciamento ambiental: no início, quando se pede aprovação das comunidades ao Plano de 


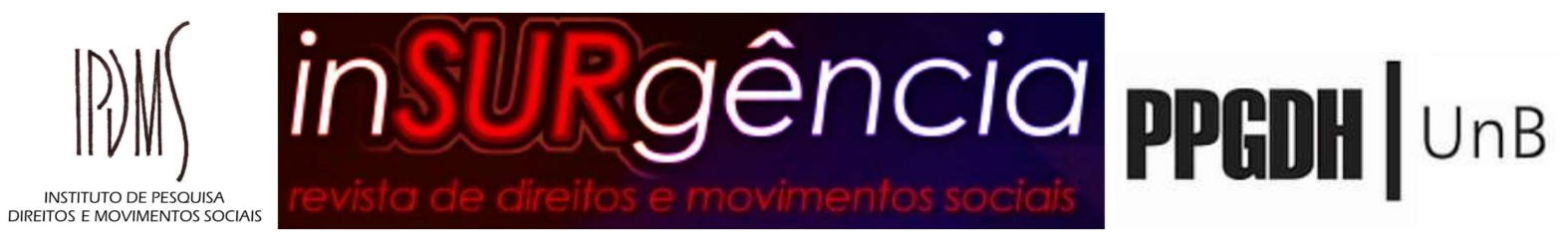

Trabalho para realização do CI-EIA e ainda aprovação dos integrantes da equipe consultora contratada pelo empreendedor para realizar os estudos. Depois, na apresentação do relatório do CI-EIA.

9. Num terceiro momento, na apresentação do Plano de Trabalho e equipe para detalhamento dos programas e ações a serem desenvolvidos no Componente Indígena do Plano Básico Ambiental (CIPBA) para mitigar ou compensar os impactos identificados do CI-EIA, na apresentação do relatório final do CI-PBA, e em qualquer outro momento, caso assim seja solicitado pelos povos indigenas. As comunidades e a Funai ainda acompanham e avaliam continuamente a execução das ações, medidas e programas doCI-PBA.

Explanou, ainda, que lhe compete, a teor do disposto no art. $2^{\circ}$ de seu Estatuto, aprovado pelo Decreto $\mathrm{n}^{\circ} 7.778 / 12$, a "garantia da proteção e conservação do meio ambiente nas terras indígenas" e a promoção do "desenvolvimento sustentável nas terras indigenas, conforme a realidade de cada povo indígena" bem como, especificamente, à Diretoria de Promoção ao Desenvolvimento Sustentável (DPDS) "promover politicas de gestão ambiental para a conservação e a recuperação do meio ambiente, monitorando e mitigando possiveis impactos ambientais decorrentes de interferências externas às terras indígenas, em articulação com os órgãos ambientais". Em prosseguimento, fez menção que a "intervenção nos processos de licenciamento decorre da salvaguarda dos interesses dos índios, como o direito à consulta prévia, conforme previsto na Convenção 169 da OIT", recepcionada pelo artigo $4^{\circ}$ do Decreto $\mathrm{n}^{\mathrm{o}} 7.747$ de 05.06.2012, que versa sobre a Política Nacional de Gestão Territorial e Ambiental de Terras Indígenas-PNGATI. Disse a FUNAI que deve pronunciar-se nos processos de licenciamento ambiental quando a atividade ou empreendimento possa ocasionar impacto socioambiental e cultural aos povos e terras indígenas, de acordo com a Instrução Normativa da Funai $\mathrm{n}^{\circ} 02$ de 27/03/2015. Concluiu que, ao conduzir o processo de licenciamento ambiental do empreendimento 'Mina Guaíba', a FEPAM não instou a FUNAI a manifestar-se no processo de licenciamento ambiental para elaboração do Estudo de

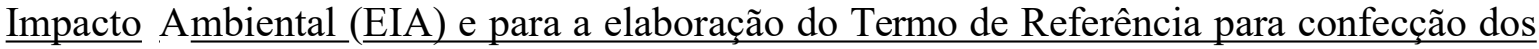
Estudos de Componente Indígena do Licenciamento Ambiental do referido empreendimento, não havendo, portanto, a inclusão do componente indígena no EIARIMA, nem consulta prévia, livre e informada às comunidades indígenas envolvidas. Aduziu que, em que pese a ausência de provocação pelo ente responsável pelo licenciamento ambiental (Fepam), já se encontra em elaboração o Termo de Referência Específico para a realização do Componente Indígena do Estudo de Impacto Ambiental (CIEIA), a ser encaminhado para a FEPAM, com cópia para o empreendedor, ao ser concluído. Juntou documentos (ev. 25).

Vieram os autos conclusos para decisão (ev. 26).

Conselho de Articulação do Povo Guarani - CAPG (associação civil sem fins lucrativos) e Comunidade da Aldeia Guarani Guajayvi (território indígena, neste ato representada pela seu Cacique Cláudio Acosta) requereram sua inclusão no feito como litisconsorte ativo necessário, com base no $\S 2^{\circ}$ do art. $5^{\circ}$ da Lei 7.347/85 (ev. 27). Disse que, dentre os diversos impactos, destacam-se, para os fins desta ação, o fato de que: "(a) os estudos apresentados pela empresa omitirem e não contemplarem satisfatoriamente o impacto às comunidades indígenas Guarani Mbya da região; (b) não incluem os obrigatórios estudos de componente indígena, conforme termo de referência encaminhado pela Fundação 


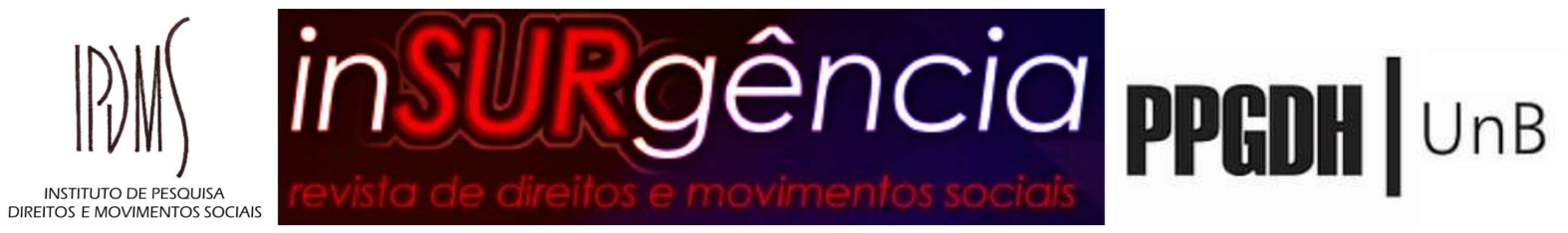

Nacional do Índio - FUNAI (fato reconhecido ao evento 25); e (c) não incluem a realização do processo de consulta livre prévia e informada, nos termos da Convenção n. 169 da OIT." (ev. 27). Disse que ante a ausência de respostas satisfatórias pela FEPAM, as comunidades indígenas não viram alternativa, senão, a judicialização do litígio. Disse que a Associação Indígena Poty Guarani, acompanhada da Associação Arayara de Educação e Cultura ajuizaram a presente Ação Civil Pública, bem como grifou que há um conjunto de indígenas diretamente atingidos pelos danos decorrentes do projeto Mina Guaíba que, também, devem participar e ser parte no presente processo. Requereu: "b) liminarmente, seja concedida a tutela antecipada pleiteada na exordial, a fim de, SUSPENDER IMEDIATAMENTE E NO ESTADO EM QUE SE ENCONTRA O PROCESSO DE LICENCIAMENTO que tramita junto a FEPAM a requerimento da COPELMI, e que pretende obter o licenciamento para instalação do denominado PROJETO MINA GUAÍBA, fixando multa diária em caso de descumprimento;", bem como: "e) no mérito, requer a total procedência da ação, confirmando a liminar de suspensão imediata do processo de licenciamento ambiental requerido pela COPELMI Mineração LTDA em trâmite perante a Fundação Estadual de Proteção Ambiental Henrique Luis Roessler; e, por conseguinte, seja declarada a nulidade do referido processo de licenciamento ambiental por não apresentar Componente Indígena, conforme termo de referência encaminhado pela Fundação Nacional do Índio ou observar processo de Consulta Livre Prévia e Informada;" (ev. 27). Requereu o benefício da AJG (ev. 27).

É o breve relatório no que releva ao momento.

Passo a decidir.

\section{DECISÃO}

\section{QUANTO ÀS PRELIMINARES}

\section{- Sobre a competência deste Juízo}

Reza o art. 109 da CF/88:

Art. 109. Aos juizes federais compete processar e julgar:

I - as causas em que a União, entidade autárquica ou empresa pública federal forem interessadas na condição de autoras, rés, assistentes ou oponentes, exceto as de falência, as de acidentes de trabalho e as sujeitas à Justiça Eleitoral e à Justiça do Trabalho;

I as causas entre Estado estrangeiro ou organismo internacional e Município ou pessoa domiciliada ou residente no País;

I as causas fundadas em tratado ou contrato da União com Estado estrangeiro ou organismo internacional; 


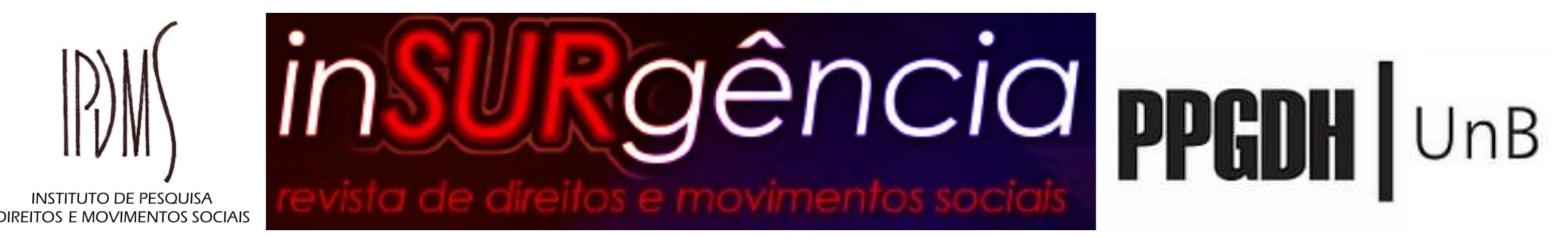

$\underline{V}$ - os crimes políticos e as infrações penais praticadas em detrimento de bens, serviços ou interesse da União ou de suas entidades autárquicas ou empresas públicas, excluídas as contravenções e ressalvada a competência da Justiça Militar e da Justiça Eleitoral;

$\underline{V}$ - os crimes previstos em tratado ou convenção internacional, quando, iniciada a execução no País, o resultado tenha ou devesse ter ocorrido no estrangeiro, ou reciprocamente;

$V$ - $A$ as causas relativas a direitos humanos a que se refere o $\S 5^{\circ}$ deste artigo; (Incluido pela Emenda Constitucional $n^{\circ} 45$, de 2004)

$V I$ - os crimes contra a organização do trabalho e, nos casos determinados por lei, contra o sistema financeiro e a ordem econômico-financeira;

VII - os habeas corpus, em matéria criminal de sua competência ou quando o constrangimento provier de autoridade cujos atos não estejam diretamente sujeitos a outra jurisdição;

VIII - os mandados de segurança e os habeas data contra ato de autoridade federal, excetuados os casos de competência dos tribunais federais;

IX - os crimes cometidos a bordo de navios ou aeronaves, ressalvada a competência da Justiça Militar;

$X$ - os crimes de ingresso ou permanência irregular de estrangeiro, a execução de carta rogatória, após o "exequatur", e de sentença estrangeira, após a homologação, as causas referentes à nacionalidade, inclusive a respectiva opção, e à naturalização;

$X I \underline{I-a \text { disputa sobre direitos indígenas. }}$

(Sublinhou-se)

Tendo a FUNAI legitimidade ad causam e encontrando-se num dos polos da relação jurídica, compete indubitavelmente a este Juízo Federal processar e julgar tal demanda, nos termos do art. 109 da CF/88.

Nesse sentido, o REsp 1.120.117-AC, Rel. Min. Eliana Calmon, julgado em 10/11/2009, cuja ementa tem o seguinte teor:

ADMINISTRATIVO E PROCESSO CIVIL - DIREITO AMBIENTALAÇÃO CIVIL PÚBLICA - COMPETÊNCIA DA JUSTIÇA FEDERAL IMPRESCRITIBILIDADE DA REPARAÇÃO DO DANO AMBIENTAL PEDIDO GENÉRICO - ARBITRAMENTO DO QUANTUM DEBEATUR NA SENTENÇA: REVISÃO, POSSIBILIDADE - SÚMULAS 284/STF E 7/STJ.

1. É da competência da Justiça Federal o processo e julgamento de Ação Civil Pública visando indenizar a comunidade indígena Ashaninka-Kampa do rio

Amônia. 
2. S egundo a jurisprudência do STJ e STF trata-se de competência territorial e $\mathrm{f}$ uncional, eis que o dano ambiental não integra apenas o foro estadual da Comarca local, sendo bem mais abrangente espraiando-se por todo o território do Estado, dentro da esfera de competência do Juiz Federal.

3. Reparação pelos danos materiais e morais, consubstanciados na extração ilegal de madeira da área indígena.

4. O dano ambiental além de atingir de imediato o bem jurídico que lhe está próximo, a comunidade indígena, também atinge a todos os integrantes do $\mathrm{E}$ stado, espraiando-se para toda a comunidade local, não indígena e para futuras gerações pela irreversibilidade do mal ocasionado.

5. Tratando-se de direito difuso, a reparação civil assume grande amplitude, com profundas implicações na espécie de responsabilidade do degradador que é objetiva, fundada no simples risco ou no simples fato da atividade danosa, independentemente da culpa do agente causador do dano.

6. O direito ao pedido de reparação de danos ambientais, dentro da logicidade hermenêutica, está protegido pelo manto da imprescritibilidade, por se tratar de direito inerente à vida, fundamental e essencial à afirmação dos povos, independentemente de não estar expresso em texto legal.

7. Em matéria de prescrição cumpre distinguir qual o bem jurídico tutelado: se eminentemente privado seguem-se os prazos normais das ações indenizatórias; se o bem jurídico é indisponível, fundamental, antecedendo a todos os demais direitos, pois sem ele não há vida, nem saúde, nem trabalho, nem lazer, considerase imprescritível o direito à reparação.

8. O dano ambiental inclui-se dentre os direitos indisponíveis e como tal está dentre os poucos acobertados pelo manto da imprescritibilidade a ação que visa reparar o dano ambiental.

9. Quando o pedido é genérico, pode o magistrado determinar, desde já, o montante da reparação, havendo elementos suficientes nos autos. Precedentes do STJ.

10. Inviável, no presente recurso especial modificar o entendimento adotado pela instância ordinária, no que tange aos valores arbitrados a título de indenização, por incidência das Súmulas 284/STF e 7/STJ.

11. Recurso especial parcialmente conhecido e não provido.

(Sublinhou-se.)

Oportuno transcrever, ainda, conciso trecho do voto condutor desse REsp 1.120.117-AC, que resume muito bem a questão, quando refere, in verbis:

\footnotetext{
"Destaco, ainda, que a ação civil pública originária envolve a disputa sobre direitos indígenas (exploração do potencial madeireiro de terra tradicionalmente ocupados pelos índios) e a FUNAI integra a relação processual como parte, o que robustece a competência da Justiça Federal da Comarca de Rio Banco/AC, que possui jurisdição sobre o município em que ocorreu o dano ambiental."
}

Assim, mudando o que deve ser mudado, tem-se como sendo a mesma situação que define a competência desta Justiça Federal para processar e julgar a presente Ação Civil Pública. 


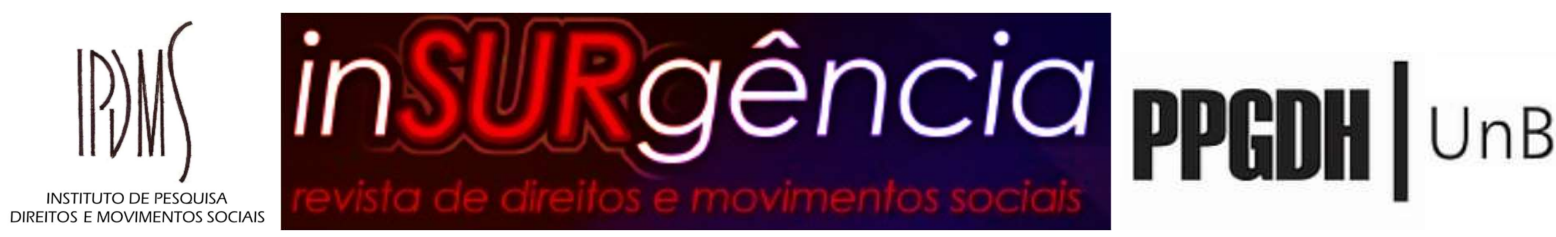

Por essas razões, rejeita-se a preliminar de incompetência deste Juízo.

- Sobre a representação processual dos autores

Pugnou a ré Copelmi pelo "(i) o indeferimento da inicial, por irregularidade na representação dos Autores, nos termos dos arts. 76, $\$ 1^{\circ}, I, 320,321$ e art. 330, IV, todos do CPC, conforme detalhado no ponto I;"

A parte autora foi intimada a regularizar sua representação processual, conforme decisão do ev. 3, tendo juntado novas procurações no ev. 7 .

Relembre-se que a ré Copelmi aduziu, no ev. 19, que as procurações juntadas no ev. 7 seguem irregulares porque: 1) faltaria comprovação de que Juliano Bueno de Araújo, apontado como representante da Associação Arayara, continue sendo seu atual Diretor Presidente; e 2) porque o instrumento da procuração juntada pela Associação Arayara não é público, conforme exigência do parágrafo único do art. 24 de seu Estatuto. Disse, ainda, que, com relação à Associação indígena, o respectivo estatuto social foi juntado de forma incompleta aos autos.

Por se tratar de meras irregularidades de representação processual, ainda sanáveis no decorrer do processamento desta demanda, mormente em caso onde o MPF opinou pelo deferimento do pleito dos autores de tutela cautelar para suspensão imediata do processo de licenciamento do projeto 'Mina Guaíba', por haver "prova inequívoca da verossimilhança do direito, isto é, da necessidade de inclusão de Componente Indígena no EIARIMA e de realização de consulta prévia livre e informada às comunidades indígenas afetadas", acrescentando que "também é evidente o risco ao direito da comunidade Mbyá- Guarani Guaijayvi pela continuidade do processo de licenciamento." (ev. 11), no bojo de ação civil pública onde, sabe-se que, quando: "Em caso de desistência infundada ou abandono da ação por associação legitimada, o Ministério Público ou outro legitimado, assumirá a titularidade ativa", nos exatos termos do $\S 3^{\circ}$ do art. $5^{\circ}$ da Lei da Ação Civil Pública, n. ${ }^{\circ} 7.347 / 85$ (com redação dada pela Lei 8.078/90).

Por essas razões, tem este Juízo como ausente questão prejudicial ao enfrentamento do pleito de urgência da parte autora neste momento processual, determinando que a parte autora se manifeste, no prazo de 15 dias, sobre as irregularidades apontadas, relativamente à representação processual, pela ora ré Copelmi no ev. 19 .

\section{- Sobre o pedido de inclusão de outras comunidades indígenas como litisconsorte ativas}

Após a conclusão desta ACP para decisão, sobreveio aos autos pedido de inclusão no feito como litisconsorte ativo necessário, com base no $\S 2^{\circ}$ do art. $5^{\circ}$ da Lei 7.347/85 de Conselho de Articulação do Povo Guarani - CAPG (associação civil sem fins 


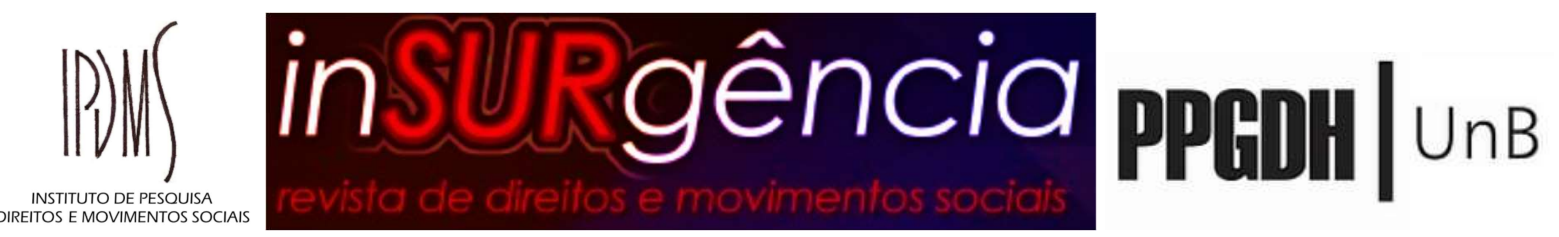

lucrativos) e Comunidade da Aldeia Guarani Guajayvi (território indígena, neste ato representada pela seu Cacique Cláudio Acosta), conforme ev. 27.

Também quanto a este ponto, tem este Juízo como ausente questão prejudicial ao enfrentamento do pleito de urgência, neste momento processual, determinando vista do pedido do ev. 27 às demais partes e ao MPF, para respectiva manifestação.

\section{- Sobre o interesse processual dos autores}

Pugnou a ré Copelmi pelo "(ii) o indeferimento da inicial, por falta de interesse processual dos Autores, nos termos do art. 330, III do CPC conforme detalhado nos pontos II e III;" (ev. 19). Relembre-se, ainda, que a ré Copelmi aduziu, no ev. 19, que o direito alegado pelos autores já está sendo respeitado, eis que Estudo de Componente Indígena ECI será realizado pela Copelmi tão logo a FUNAI expeça o Termo de Referência Específico - TRE. Disse que a participação da FUNAI no licenciamento ambiental garante a realização da consulta prevista pela Convenção 169 da OIT. Salientou que o Estudo de Componente Indígena será realizado pela Copelmi, que nunca se opôs a tal realização. Disse que a empresa está aguardando a expedição do respectivo Termo de Referência Especificado TRE pela FUNAI, atualmente em elaboração, que além de ser de competência deste ente, é essencial para a delimitação do conteúdo a ser estudado. Salientou que, em casos de empreendimentos minerários situados fora da Amazônia Legal, presumem-se impactos diretos se a terra indígena estiver localizada dentro do raio de $8 \mathrm{~km}$ do empreendimento. Entende pela existência de uma terra indígena em estudo no entorno do empreendimento: a Terra Indígena em estudo Arroio do Conde, no Município de Eldorado do Sul. Disse que, feitas essas verificações, a partir dos dados públicos disponibilizados pela própria FUNAI, a Copelmi estava segura quanto à regularidade dos procedimentos que vinham até então sendo adotados.

Disse que, em julho de 2019, recebeu solicitação da FUNAI sobre dados locacionais do projeto 'Mina Guaíba'. Disse que as informações foram prestadas pela Copelmi em 07/08/2019 e que, até dezembro de 2019, ainda aguardava a resposta da FUNAI, quanto à necessidade de sua participação no licenciamento ambiental como de ser necessária a realização de Estudo do Componente Indígena - ECI. Disse que, em 14/01/2019 (sic), requereu à FUNAI a expedição do Termo de Referência Específico para poder dar início ao ECI. Đisse que a realização do ECI, que motivou o ingresso da presente ação, está devidamente resguardada, sendo que não foi iniciada porque aguarda o Termo de Referência Específico a ser expedido pela FUNAI, que norteará o estudo específico. Disse que da mesma forma encontra-se resguardada a consulta prévia de que trata a Convenção 169 da OIT, porquanto já há participação da FUNAI no processo de licenciamento ambiental do Projeto 'Mina Guaíba'. Salientou que o processo de licenciamento encontra-se na fase de Licença Prévia - LP, etapa destinada a declarar a viabilidade ambiental, ou não, do empreendimento proposto, não havendo a menor necessidade/utilidade da tutela judicial requerida. Registrou, por fim, que "embora a Aldeia (TeKoá) Guajayvi não conste como terra indígena na base de dados da FUNAI [independentemente da modalidade ou fase de regularização], ela teve a sua presença identificada pelo órgão indigenista no âmbito do processo administrativo $n^{\circ}$ 08620.007497/2019-10, onde este também consignou a informação de que 'A Funai está realizando tratativas com o Governo do Rio Grande do Sul para a possibilidade de repasse desta área para os indígenas' [OUT9, pg. 8]. Tal área, contudo, está localizada dentro do Horto Carola, de propriedade da Companhia Estadual de Energia Elétrica 


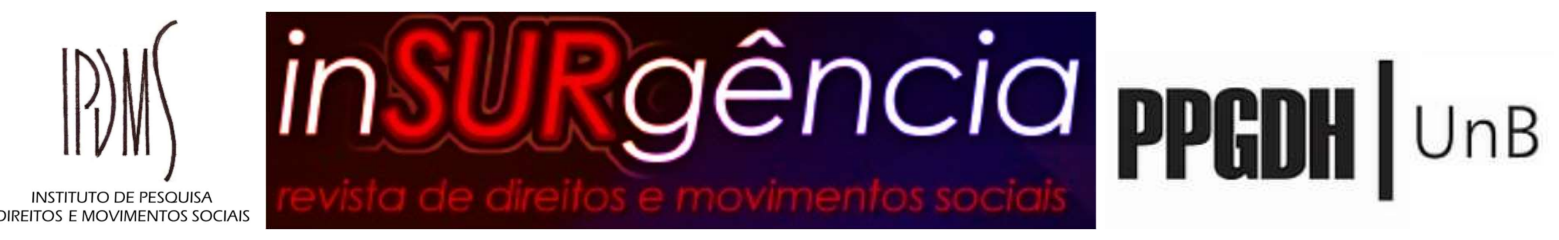

- CEEE, o qual está sendo objeto de investigação detalhada de contaminação do solo, tendo em vista o funcionamento pretérito de uma Unidade de Preservação de Madeira que operava no local. O procedimento de investigação é resultado de um Termo de Compromisso de Ajustamento de Conduta firmado entre o Ministério Público do Estado do Rio Grande do Sul e a CEEE, cujos estudos ainda se encontram em andamento, segundo informou a FEPAM [OUT9, pg. 1-2]. Considerando que a contaminação desta área já havia motivado a retirada de famílias do Movimento Sem Terra-MST que haviam ocupado parte do Horto Carola, desocupação esta acordada no bojo de ação judicial sentenciada por V.Exa.8, a Copelmi informou a FUNAI a respeito, assim como endereçou questionamento por e-mail à FEPAM, responsável pelo licenciamento ambiental da descontaminação, acerca da possibilidade/segurança relacionada à permanência das famílias indígenas naquele local. Em resposta, a FEPAM informou não ter conhecimento do agrupamento indigena no imóvel, mas que havia provocado a CEEE para se manifestar a respeito [OUT8, pg. 34, OUT9, pg. 1-2]." (ev. 19).

Entretanto, consta dos autos, parecer do digno representante do Ministério Público Federal, Procurador da República, Dr. Pedro Nicolau Moura Sacco, no qual registrou textualmente: "Assiste razão aos autores ao afirmarem que o EIA apresentado pela Copelmi Mineração Ltda, no bojo do processo de licenciamento ambiental do projeto Mina Guaíba, nada menciona a propósito da terra indígena Guajaivy. Esta terra indígena dista pouco mais de 1 quilometro da Area Diretamente Afetada - ADA do empreendimento, bem como está dentro da sua Área de Influência Direta - AID, conforme os limites da AID propostos no EIA-RIMA para os meios físico, biótico e socioeconômico (vide, a propósito, estudo preliminar anexo da FUNAI - Oficio n. ${ }^{\circ}$ 26-2019-CTL-Porto Alegre). A terra indígena Guajayví está inserida em imóvel de 1080 hectares, de propriedade da Companhia Estadual de Distribuição de Energia Elétrica CEEE-D, que cedeu 297,2 hectares da área para o Estado do Rio Grande do Sul, em 2014, para cumprir a função de assentamento indígena, como esclarecem o Termo de Cessão de Uso e a Declaração em anexo." (ev. 11).

Consta, ainda, conforme trazido pela FUNAI (ev. 25), a Informação Técnica ${ }^{\circ}$ 17/2020, elaborada pela Coordenação-Geral de Licenciamento Ambiental, que: "2. Primeiramente, comunicamos que a Coordenação-Geral de Licenciamento Ambiental (CGLic) tomou conhecimento do referido empreendimento somente por meio de oficio encaminhado pelo Conselho Estadual dos Povos Indígenas (CEPI) e por meio de oficio da Procuradoria da República no Rio Grande do Sul encaminhado à unidade descentralizada da Funai em Porto Alegre, não tendo sido, portanto, instada pela Fundação Estadual de Proteção Ambiental Henrique Luis Roessler (FEPAM) a se manifestar no processo de licenciamento ambiental antes da emissão do Termo de Referência para elaboração do Estudo de Impacto Ambiental (EIA) do empreendimento." (ev. 25).

Por essas razões e considerando tudo o que consta dos autos até o presente momento, entende este Juízo que tal questão preliminar confunde-se, em verdade, com o objeto desta ação, devendo ser afastada a alegação de falta de interesse processual da parte autora, para que o mérito da ação possa ser enfrentado, tanto em sede de liminar, quanto ao final, por ocasião da prolação de sentença. 


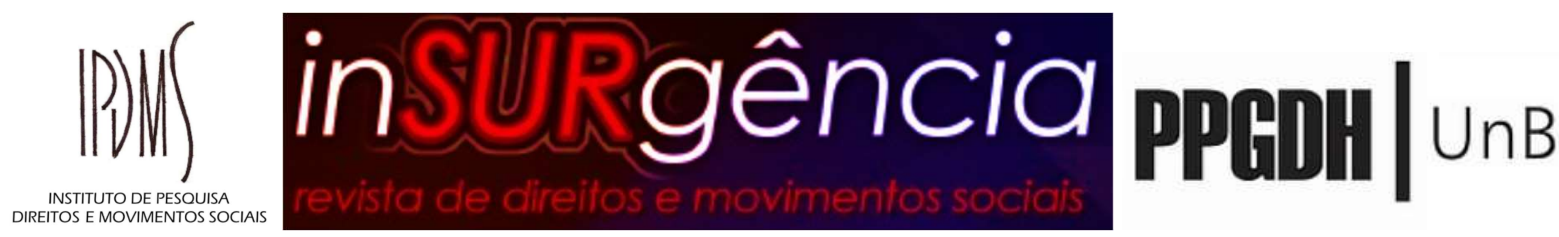

QUANTO AO PLEITO LIMINAR

Registre-se, inicialmente, que se está diante de pedido de licenciamento ambiental para empreendimento denominado Projeto Mina Guaíba, requerido pela ora ré Copelmi, em 17/10/2018, conforme referido pela Fepam, no ev. 22, que tomou o número 6354-05.67/18-1, cuja atividade principal é a extração mineral de carvão em área de 5.000 hectares, localizada entre os municípios gaúchos de Eldorado do Sul e de Charqueadas.

Relembre-se que a parte autora requereu a concessão de tutela cautelar antecedente para determinar a imediata suspensão do processo de licenciamento do empreendimento denominado 'PROJETO MINA GUAÍBA', no estado em que se encontra, que tramita na Fundação Estadual de Proteção Ambiental Henrique Luis Roessler - FEPAM, a pedido de Copelmi Mineração LTDA., em apertada síntese, em razão da ausência no Estudo de Impacto Ambiental apresentado pelo empreendedor de Componente Indígena referente à comunidade Mbyá-Guarani Guajayvi, bem como da consulta prévia à referida comunidade prevista na Convenção 169 da OIT.

As comunidades indígenas que posteriormente pediram inclusão no polo ativo da ação (Conselho de Articulação do Povo Guarani - CAPG e Comunidade da Aldeia Guarani Guajayvi - território indígena, representado por seu Cacique - ev. 27), cuja admissão ainda pende de prévia oitiva das demais partes do processo e de definição por este Juízo, também requereram liminar no mesmo sentido, isto é, para que "seja concedida a tutela antecipada pleiteada na exordial, a fim de, SUSPENDER IMEDIATAMENTE E NO ESTADO EM QUE SE ENCONTRA O PROCESSO DE LICENCIAMENTO que tramita junto a FEPAM a requerimento da COPELMI, e que pretende obter o licenciamento para instalação do denominado PROJETO MINA GUAÍBA" (ev. 27).

Abre-se um parêntesis apenas para salientar uma vez mais que, embora ainda não admitidas no polo ativo desta ACP, o pleito liminar é o mesmo requerido pelas ora autoras: Associação Arayara de Educação e Cultura e a Associação Indígena Poty Guarani que será examinado na presente decisão, não havendo prejuízo, portanto.

Recorde-se que a ora ré Copelmi pugnou, no ponto, pelo "(iii) o indeferimento da tutela provisória, caso V.Exa. supere as preliminares acima, por ausência dos requisitos do art. 300 do CPC, nos termos detalhados nos pontos II e III." (ev. 19); que a ora ré Fepam, após prestar suas informações, manifestou-se pelo indeferimento da tutela cautelar requerida, destacando que "não possui qualquer interesse em se opor à interveniência da FUNAI. Inclusive, conforme oficio de informação da Divisão de Mineração da FEPAM ao Empreendedor, cópia em anexo, a Fundação aguarda resposta da FENAI para elaboração dos estudos referentes ao componente indigena" (ev. 22).

Rememore-se, por fim, que a FUNAI, após prestar suas informações, concluiu "que não houve a inclusão do componente indígena no EIA-RIMA, nem consulta prévia, livre e informada às comunidades indígenas envolvidas, muito embora, no momento, esteja sendo elaborado o estudo em questão." (ev. 25); e que o Ministério Público Federal, por seu turno, apresentou parecer, manifestando-se favoravelmente ao pedido de tutela cautelar dos autores para suspensão imediata do processo de licenciamento do projeto Mina Guaíba, por haver "prova 


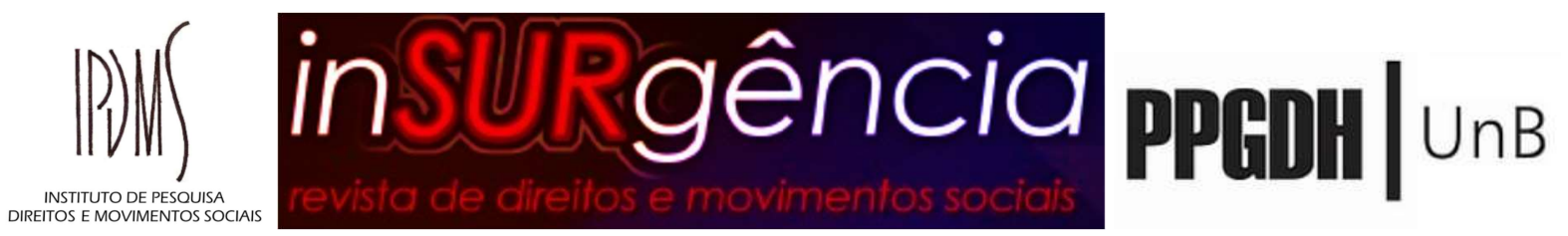

inequivoca da verossimilhança do direito, isto é, da necessidade de inclusão de Componente Indígena no EIA-RIMA e de realização de consulta prévia livre e informada às comunidades indigenas afetadas", acrescentando "também é evidente o risco ao direito da comunidade MbyáGuarani Guaijayvi pela continuidade do processo de licenciamento." (ev. 11).

Tem-se que o CPC de 2015 traz, no seu capítulo 'Disposições Gerais', os seguintes requisitos para deferimento da Tutela de Urgência, in verbis:

Art. 300. A tutela de urgência será concedida quando houver elementos que evidenciem a probabilidade do direito e o perigo de dano ou o risco ao resultado útil do processo.

\section{(...)}

$\S 3^{\circ}$ A tutela de urgência de natureza antecipada não será concedida quando houver perigo de irreversibilidade dos efeitos da decisão.

No caso em tela, verifica-se a configuração dos dois requisitos para o deferimento: tanto a probabilidade do direito como o perigo de dano estão presentes.

Quanto à probabilidade do direito, entende-se configurada, ao menos nesse juízo sumário, em face mormente das informações trazidas pelas comunidades indígenas representadas pela parte autora (ev. 1), como daquelas que pediram ingresso como litisconsortes ativas (ev. 27) -, e confirmadas pela FUNAI, que trouxe aos autos a Informação Técnica ${ }^{\circ}$ 17/2020, elaborada pela Coordenação-Geral de Licenciamento Ambiental, que registra de forma explícita que, in verbis:

2. Primeiramente, comunicamos que a Coordenação-Geral de Licenciamento Ambiental (CGLic) tomou conhecimento do referido empreendimento somente por meio de oficio encaminhado pelo Conselho Estadual dos Povos Indigenas (CEPI) e por meio de ofício da Procuradoria da República no Rio Grande do Sul encaminhado à unidade descentralizada da Funai em Porto Alegre, na ão tendo sido, portanto, instada pela Fundação Estadual de Proteção Ambiental Henrique Luis Roessler (FEPAM) a se manifestar no processo de licenciamento ambiental antes da emissão do Termo de Referência para elaboração do Estudo de Impacto Ambiental (EIA) do empreendimento.

$$
\text { (...) }
$$

4. Após a conclusão das análises pela Diretoria de Proteção Territorial (DPT) da Funai, constatou-se que o projeto encontra-se a $6.95 \mathrm{~km}$ da Terra Indígena Arroio do Conde, a $1.82 \mathrm{~km}$ da Aldeia Guajayví e a 6.12 km da reivindicação de área denominada Pekuruty/Arroio Divisa; portanto, dentro da distância estabelecida no Anexo I da Portaria Interministerial $n^{\circ}$ 60/15 para empreendimentos dessa tipologia fora da Amazônia Legal.

(Sublinhou-se.)

O MPF referenda tal constatação em seu parecer do ev. 11, especialmente quando registra: 


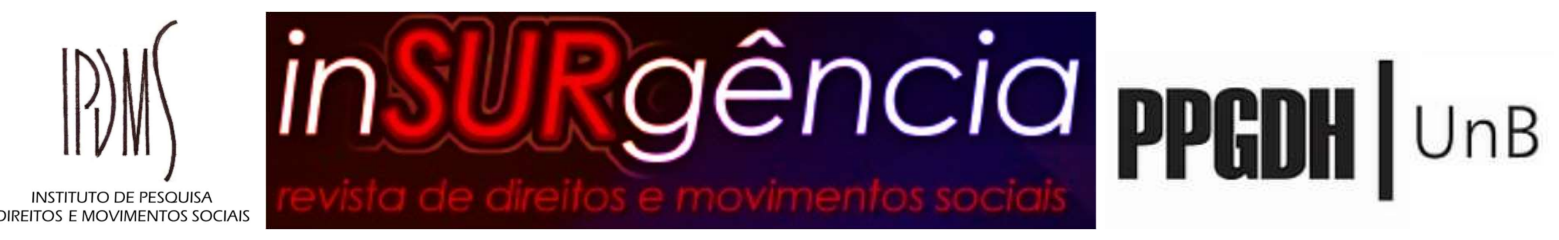

Assiste razão aos autores ao afirmarem que o EIA apresentado pela Copelmi Mineração Ltda, no bojo do processo de licenciamento ambiental do projeto Mina Guaíba, nada menciona a propósito da terra indígena Guajaivy. Esta terra indígena dista pouco mais de 1 quilometro da Área Diretamente Afetada - ADA do empreendimento, bem como está dentro da sua Área de Influência Direta - AID, conforme os limites da AID propostos no EIA-RIMA para os meios físico, biótico e socioeconômico (vide, a propósito, estudo preliminar anexo da FUNAI-Ofício n. ${ }^{\circ}$ 26-2019-CTL-Porto Alegre).

\section{(...)}

Cabe lembrar que a Portaria Interministerial $n .^{\circ}$ 60, de 24 de março de 2015, e a Instrução Normativa $n .^{\circ} 2$, de 27 de março de 2015, estabelecem que a Fundação Nacional do Índio FUNAI deve participar dos processos de licenciamento ambiental, quando houver impactos socioambientais diretos a povos e terras indígenas, localizados no limite de 8 quilometros do empreendimento submetido ao licenciamento, no caso de mineração em região distinta da Amazônia Legal. Incumbe à FUNAI, por meio da Coordenação Geral de Licenciamento da Diretoria de Promoção ao Desenvolvimento Sustentável, consolidar Termo de Referência Específico, contendo as exigências de informações ou de estudos específicos referentes ao impacto socioambiental de empreendimento em terra indígena, a fim de subsidiar a realização pelo empreendedor dos estudos dos impactos relativos ao componente indígena do licenciamento. Ademais, a FUNAI analisará o Estudo do Componente Indígena do EIA-RIMA, podendo recomendar o prosseguimento do processo de licenciamento, sob a ótica do componente indígena, ou apontar a existência de eventuais óbices ao processo de licenciamento e as medidas ou condicionantes consideradas necessárias para superá-los.

\section{(...)}

Desse modo, a FUNAI veio a saber do empreendimento Mina Guaíba e de suas repercussões nas aldeias Guajayvi e Pekuruty apenas em função de informações recebidas do MPF e do Conselho Estadual dos Povos Indígenas - CEPI. Note-se que não apenas a TI Guajayvi, enfocada nesta ação, está a menos de 8 quilômetros da ADA, mas também a comunidade MbyáGuarani Pekuruty ou comunidade do Arroio Divisa.

\section{(...)}

Ante todo o exposto, o Ministério Público Federal manifesta-se favoravelmente ao pedido dos autores de tutela cautelar para suspensão imediata do processo de licenciamento do projeto Mina Guaiba, pois há prova inequívoca da verossimilhança do direito, isto é, da necessidade de inclusão de Componente Indígena no EIA-RIMA e de realização de consulta prévia livre e informada às comunidades indígenas afetadas. Também é evidente o risco ao direito da comunidade Mbyá-Guarani Guaijayvi pela continuidade do processo de licenciamento.

Entende-se que a continuidade do procedimento de licenciamento ambiental do Projeto 'Mina Guaíba', como está - sem a necessária inclusão de Estudo do Componente Indígena (ECI) a integrar o EIA/RIMA, bem como sem a oitiva das comunidades indígenas afetadas, tudo previamente à eventual emissão de Licença Prévia (LP) ao empreendimento - evidentemente causará prejuízos irreparáveis (perigo de dano caracterizado), uma vez que inexistentes os estudos obrigatórios no que pertine aos impactos sociais, culturais e ambientais do componente indígena. Cabendo lembrar que a oitiva prévia das comunidades indígenas afetadas por empreendimento de tal impacto se constitui em obrigação decorrente da Convenção 169 do OIT, da qual é signatária a República Federativa do Brasil. 


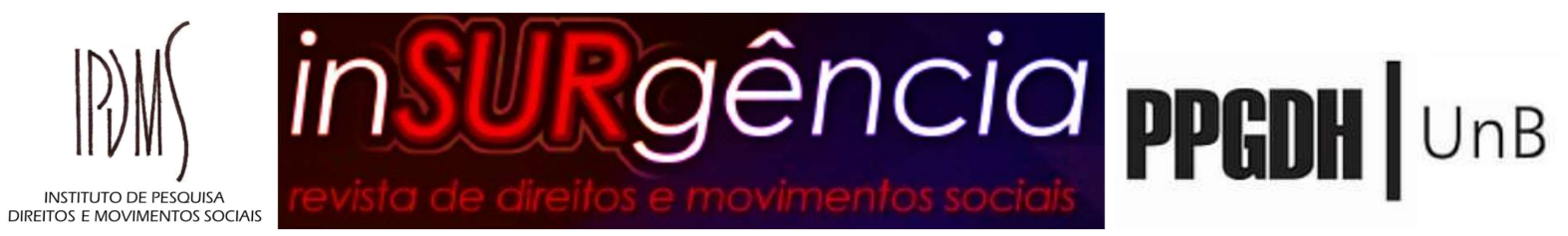

Pontue-se, ainda, que embora reste incontroverso nestes autos judiciais que a FUNAI deve participar do processo de licenciamento ambiental do Projeto Mina Guaíba, conforme se verifica de todas as manifestações das partes constantes destes autos eletrônicos, dessume-se que a posição do órgão ambiental estadual (Fepam) restou ambígua, senão omissa, primeiro por não instar o ente federal FUNAI a se manifestar no referido licenciamento ambiental, segundo, por entender que o referido licenciamento poderia continuar se processando, até mesmo com a expedição de Licença Prévia - LP, antes mesmo da existência e análise (sobre a pertinência e suficiência) de Estudo do Componente Indígena (ECI) que deve integrar o EIA/RIMA em questão e antes da prévia oitiva das comunidades indígenas afetadas.

Sabe-se que a Licença Prévia - LP é a licença concedida na fase preliminar do planejamento do empreendimento ou atividade, aprovando sua localização e concepções, atestando a viabilidade ambiental e estabelecendo os requisitos básicos e condicionantes a serem atendidos nas próximas fases de sua implantação. Assim, embora a Fepam tenha referido em suas informações que a LP, quando concedida pelo órgão ambiental, não autoriza a implantação do empreendimento, a penas aprovando a sua localização e concepção, temse que, justamente por essas razões, mormente locacionais e das condicionantes iniciais a serem atendidas, não pode ser expedida LP sem a prévia análise do ECI que deve integrar o EIA/RIMA e sem a prévia oitiva das comunidades indígenas afetadas. Isso não quer significar que se está a exigir que os Estudos de Impacto Ambiental sejam exaurientes antes da concessão da LP, mas apenas que o Estudo de Componente Indígena (ECI) faça parte integrante do EIA/RIMA antes da concessão da LP e que seja ouvida previamente a comunidade indígena afetada, sendo possíveis complementações mesmo depois da eventual concessão de licença ambiental.

Reza a Instrução Normativa IN nº 2, de 27/03/2015, da FUNAI que:

Art. $1^{\circ}$ Esta Instrução Normativa estabelece procedimentos administrativos a serem observados pela Fundação Nacional do Índio - F unai, quando instada a se manifestar nos processos de licenciamento ambiental federal, estadual e municipal, em razão da existência de impactos socioambientais e culturais aos povos e terras indígenas decorrentes da atividade ou $e$ mpreendimento objeto do licenciamento.

Art. $2^{\circ}$ A manifestação da Funai ocorrerá nos processos de licenciamento ambiental de atividades ou empreendimentos: I - localizados nas terras indigenas a que se refere o inciso XII do art. $2^{\circ}$ da Portaria Interministerial $n^{\circ}$ 60, de 24 de março de 2015; e II - que possam ocasionar impacto socioambiental direto nas áreas mencionadas no inciso I, considerados os limites estabelecidos pelo Anexo I da Portaria Interministerial $n^{\circ}$ 60, de 24 de março de 2015.

Art. $3^{\circ}$ A Funai se manifestará nos processos de licenciamento ambiental a partir da solicitação formal do órgão ambiental li c e n c i a d o $r$.

(...)

Art. $4^{\circ}$ Instada pelo órgão ambiental licenciador a se manifestar, a Funai, por meio da oordenação Geral de Licenciamento - CGLIC da Diretoria de Promocão ao 


\section{|Pil|

esenvolvimento Sustentável - DPDS deverá instaurar processo administrativo interno para s ubsidiar sua manifestação.

\section{(...)}

Art. $7^{\circ}$ Após a consulta referida no art. $6^{\circ}$, a CGLIC consolidará Termo de Referência Específico contendo as exigências de informações ou de estudos específicos referentes à $i$ ntervenção da atividade ou empreendimento em terra indígena, a fim de subsidiar ar ealização dos estudos dos impactos relativos ao componente indígena do licenciamento.

\section{(...)}

Art. $8^{\circ}$ Instada pelo órgão ambiental licenciador a se manifestar em relação aos estudos ambientais, a Funai, por meio da CGLIC, analisará, mediante parecer técnico, os estudos do componente indígena a partir da verificação dos seguintes itens: I - o cumprimento do Termo de Referência Específico; II - a avaliação da matriz de impactos socioambientais, sob a óptica do componente indígena; e III - a relação de causa e efeito entre os impactos apontados no estudo e as medidas propostas para a sua mitigação e controle ambiental.

Parágrafo único: A Funai deverá, ainda, considerar documento específico elaborado pelo empreendedor, complementar aos estudos, desde que este seja apresentado ao órgão licenciador competente e, em caso de concordância, encaminhado ou disponibilizado pelo referido órgão à Funai.

Art. $9^{\circ} \mathrm{O}$ parecer referido no art. $8^{\circ}$ será aprovado por despacho do Coordenador-Geral da CGLIC, que poderá recomendar à DPDS, de forma motivada, que os estudos sejam: I considerados aptos à apresentação para as comunidades indígenas; II - esclarecidos, detalhados ou complementados pelo empreendedor; ou III - considerados inaptos à apresentação para as comunidades indígenas. $\quad \& 1^{\circ} \mathrm{O}$ s estudos considerados aptos pela DPDS serão apresentados às comunidades indígenas afetadas, em linguagem acessivel ou $c$ om tradução para línguas maternas, com apoio do empreendedor, sempre que necessário.

$\$ 2^{\circ}$ A apresentacão e a oitiva das comunidades indígenas serão realizadas por equipe técnica d a CGLIC, antes da elaboração de seu parecer final sobre os $e$ studos.

$\S 3^{\circ}$ No caso previsto no inciso II, acatada a recomendação constante do despacho da CGLIC, o Diretor da DPDS fará as devidas solicitações por meio de ofício ao empreendedor.

$\$ 4^{\circ}$ O pedido de esclarecimentos, detalhamentos ou complementacões referido no inciso II do caput poderá ser feito uma única vez, mediante decisão motivada, e deverá ser entregue pelo e mpreendedor.

$\S 5^{\circ} \mathrm{A}$ contagem do prazo previsto no art. $7^{\circ}$ da Portaria Interministerial $n^{\circ} 60$, de 24 de março de 2015, será suspensa durante a elaboração do pedido de esclarecimentos, detalhamentos ou complementações.

$\S 6^{\circ} \mathrm{O}$ órgão ambiental licenciador deverá ser comunicado da suspensão de prazo referida no $\S 5^{\circ}$.

Art. 10. Após a apresentação e oitiva das comunidades indígenas, a CGLIC emitirá o parecer $t$ écnico final, podendo recomendar à DPDS que os estudos sejam.

I - aprovados;

I- aprovados, com ressalvas; $O$

u III-reprovados.

Art. 11. A FUNAI emitirá, por meio de ofício do Diretor da DPDS, sua manifestação conclusiva, podendo:

I - recomendar o prosseguimento do processo de licenciamento, sob a óptica do componente $i$ ndigena; 


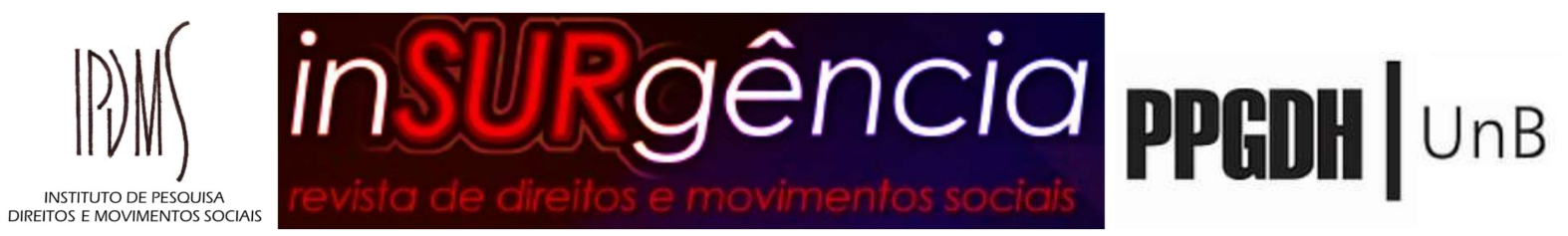

ou II - apontar a existência de eventuais óbices ao prosseguimento do processo del icenciamento, sob a óptica do componente indigena, indicando, sempre que possível, as $\quad m$ edidas ou condicionantes consideradas necessárias para superá-los.

Parágrafo único. A manifestação conclusiva será encaminhada no prazo de até noventa dias no caso de EIA/RIMA e de até trinta dias nos demais casos, a contar da data de recebimento da solicitação do órgão ambiental licenciador.

Art. 12. Instada a se manifestar pelo órgão ambiental licenciador no período que antecede a emissão da licença de instalação, a Funai, por meio da CGLIC, analisará, mediante parecer técnico, os programas previstos no Projeto Básico Ambiental - PBA ou documento equivalente definidor do conjunto de planos, programas, projetos e medidas de controle ambiental, a partir da verificação dos seguintes itens:

I - adequação e pertinência do conteúdo do documento;

II - relação de causa e efeito entre os impactos apontados no estudo e as medidas propostas;

e III - sustentabilidade socioambiental das medidas propostas.

(Conforme 'OUT2' do ev. 25 destes autos eletrônicos.)

Assim, conclui-se que, para que o órgão licenciador estadual (Fepam), possa fazer sua análise quanto à expedição ou não de Licença Prévia - LP ao empreendimento, deve-se aguardar o iter procedimental vigente, qual seja, a elaboração de Termo de Referência Específico (TRE) a ser emitido pela FUNAI, para que seja feito o devido Estudo do Componente Indígena (ECI) a integrar o EIA/RIMA pelo empreendedor, para, então, ser analisado pela FUNAI e, após remetido ao órgão licenciador (Fepam) para análise do EIA/RIMA, incluso aí o ECI. Tudo, em face da importância de que o licenciamento ambiental seja conduzido de forma a solucionar, de forma efetiva, os impactos sociais, culturais eambientais relacionados ao componente indígena no entorno do empreendimento, bem como da importância de ser observada, também de forma efetiva, as normas que determinam a realização de consulta também prévia livre e informada às comunidades indígenas afetadas, nos termos da Convenção 169 da OIT.

Não obstante refira a ora ré Copelmi que o licenciamento ambiental do Projeto Mina Guaíba está em processamento desde 2014 (ev. 19 - item 30), sem que sequer tenha sido expedida a Licença Prévia - LP, vê-se que a Fepam indica que o pedido data de 17/10/2018 (ev. 22). Mesmo assim, entende-se pela necessidade do deferimento da tutela cautelar antecedente, para o fim de que se aguarde os elementos essenciais e prévios (análise do Estudo do Componente Indígena a integrar o EIA/RIMA e oitiva das comunidades indígenas afetas), sem os quais o licenciamento ambiental não pode prosseguir.

Esclareça-se, por oportuno, que a "suspensão" ora determinada, em verdade, se trata de determinação de que o iter próprio do procedimento licenciatório deve aguardar tais elementos essenciais sem os quais não pode e não deve prosseguir.

Ademais, verifica-se que a FUNAI informou no ev. 25 que, em que pese a ausência de provocação pelo ente responsável pelo licenciamento ambiental (Fepam), já se encontra em elaboração o Termo de Referência Específico para a realização do Componente 


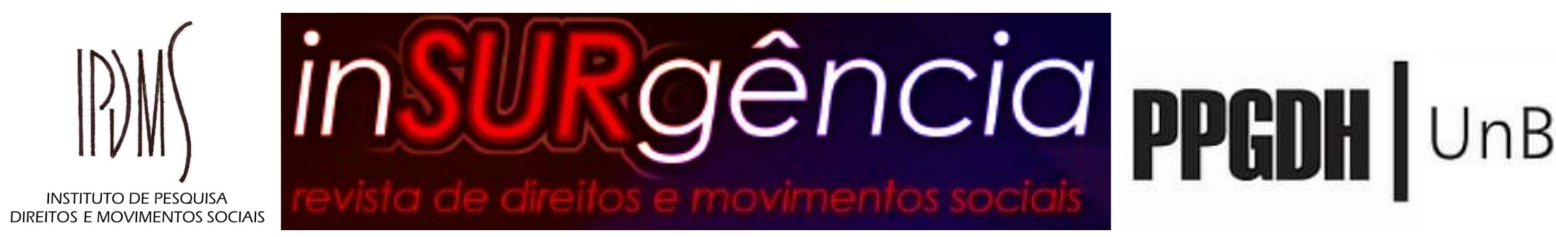

Indígena do Estudo de Impacto Ambiental (CI-EIA), a ser encaminhado para a Fepam, com cópia para o empreendedor, ao ser concluído.

Por essas razões:

a) rejeita-se a preliminar de incompetência deste Juízo;

b) tem este Juízo como ausente questão prejudicial ao enfrentamento do pleito de urgência da parte autora, relativamente à suposta irregularidade na representação processual da parte autora, neste momento processual, determinando que a parte autora se manifeste, no prazo de 15 dias, sobre as irregularidades apontadas, relativamente à sua representação processual, pela ora ré Copelmi no ev. 19;

c) tem este Juízo como ausente questão prejudicial ao enfrentamento do pleito de urgência da parte autora, relativamente ao pedido de inclusão no polo ativo de outras comunidades indígenas, neste momento processual, determinando vista do pedido do ev. 27 às demais partes e ao MPF, para respectiva manifestação;

d) afasta-se a preliminar de falta de interesse processual da parte autora porque tal questão confunde-se, em verdade, com o objeto desta ação, devendo ser enfrentado o mérito da ação, tanto em sede de liminar, quanto ao final, por ocasião da prolação de sentença; e

e) DEFIRO O PLEITO LIMINAR DA PARTE AUTORA DE TUTELA CAUTELAR ANTECEDENTE PARA SUSPENDER IMEDIATAMENTE E NO ESTADO EM QUE SE ENCONTRA O PROCESSO DE LICENCIAMENTO AMBIENTAL DO PROJETO MINA GUAÍBA, que tramita perante a Fepam, a requerimento da ora ré Copelmi, até a análise conclusiva pela FUNAI do componente indígena a ser incluído no Estudo de Impacto Ambiental e respectivo Relatório de Impacto Ambiental (EIA/RIMA), anteriormente à emissão de eventual Licença Prévia pela Fepam, em face da importância de que o licenciamento ambiental seja conduzido de forma a solucionar os impactos sociais, culturais e ambientais relacionados ao componente indígena no entorno do empreendimento, bem como da importância de ser observada, de forma efetiva, as normas que determinam a realização de consulta também prévia livre e informada às comunidades indígenas afetadas, nos termos da Convenção 169 da OIT.

Intimem-se as partes, com urgência, para ciência do inteiro teor da presente decisão, bem como para seu cumprimento. 